UCRL-PROC-206169

LA WRENCE LIWEAMCAE WATIONAL LABOAAT OAY
Scientific Challenges for Ensuring Clean and Reliable Water for the $21^{\mathrm{sT}}$ Century

Andrew F. B. Tompson

Lawrence Livermore National Laboratory

Livermore, CA 94550

\section{August 2004}

Erice International Seminars on Nuclear War, Planetary Emergencies and Associated Events Erice, Italy

August 18-23, 2004 
This document was prepared as an account of work sponsored by an agency of the United States Government. Neither the United States Government nor the University of California nor any of their employees, makes any warranty, express or implied, or assumes any legal liability or responsibility for the accuracy, completeness, or usefulness of any information, apparatus, product, or process disclosed, or represents that its use would not infringe privately owned rights. Reference herein to any specific commercial product, process, or service by trade name, trademark, manufacturer, or otherwise, does not necessarily constitute or imply its endorsement, recommendation, or favoring by the United States Government or the University of California. The views and opinions of authors expressed herein do not necessarily state or reflect those of the United States Government or the University of California, and shall not be used for advertising or product endorsement purposes.

This work was performed under the auspices of the U.S. Department of Energy by University of California, Lawrence Livermore National Laboratory under Contract W-7405-Eng-48. 


\title{
SCIENTIFIC CHALLENGES FOR ENSURING CLEAN AND RELIABLE WATER FOR THE 21ST CENTURY
}

\author{
ANDREW F. B. TOMPSON \\ Lawrence Livermore National Laboratory, Livermore, CA 94550 USA \\ INTRODUCTION
}

Many areas in the world are experiencing significant fresh water shortages due to drought, growing populations, increased agricultural and industrial demands, and extensive forms of pollution or water quality degradation ${ }^{1}$. Many more are expected to face similar predicaments in the next 20 years. Water shortages will significantly limit economic growth, decrease the quality of life and human health for billions of people, degrade the ecologic health of natural environments, and could potentially lead to violence and conflict over securing scarce supplies of water. These concerns are not limited to the economically poor countries, of course, as many parts of the United States face similar dilemmas. These problems can be exacerbated by fluctuating imbalances between need and supply, poor water management or land use practices, social, economic, political, and trans-boundary disputes, as well as factors related to climate change. The future is one that will require significant technological advances to support the conservation, preservation, and movement of fresh water, as well as in the development of new or alternative supplies. It is also one that will also require concomitant improvements in the use of practical solutions and the ways in which the broader scientific and technical community interacts with policy-makers, water-related agencies, the educational community, as well the public in the solution process. This presentation will review several aspects of these issues and proposed or implemented solutions for new and reliable water in the context of an example water situation in the US.

\section{WATER IN THE AMERICAN WEST}

In the past decades, population growth and droughts in California have highlighted and refocused attention on the problem of providing reliable sources of water to sustain the State's future economic development. Specific elements of concern include not only the stability and availability of future water supplies in the $\mathrm{State}^{2}$, but also how current surface and groundwater storage and distribution systems may be more effectively managed and upgraded, how increasingly degraded water supplies may be improved or treated, how the water needs of natural ecosystems may be met, as well as how legislative, regulatory, and economic processes may be used or modified to address conflicts between advocates of urban growth, industrial, agricultural, and environmental concerns. 
California is not alone with respect to these issues. They are clearly relevant throughout the West, and are becoming more so in other parts of the US. They have become increasingly important in developing and highly populated nations such as China, India, and Mexico. And they are critically important in the Middle East, especially as they relate to regional stability and security issues. Indeed, in almost all cases, there are underlying themes of "reliability" and "sustainability" that pertain to the assurance of current and future water supplies, as well as a broader set of "stability" and "security" issues that relate to these assurances - or lack thereof - to the political and economic future of various countries and regions. Moreover, water quality is becoming an equally or more important concern in many parts of the world, either as a result of long term agricultural or industrial contamination, or as a result of naturally poor or saline waters being used for routine domestic supplies.

The water supply and quality situation in the United States is replete with many examples of the issues outlined above. Consider, for instance:

- Chemical contamination of surface and subsurface waters, as caused or induced by agricultural, industrial, and defense related activities over the past century, has been recognized as an important and widespread problem ${ }^{3}$ affecting drinking water supplies and the health of natural ecosystems, yet one that has proven to be extremely costly to address.

- Pathogenic contamination of drinking water, often associated with isolated septic tank or wastewater discharges, has received more attention recently as a result of water borne illnesses attributed to Cryptosporidium in Milwaukee, WI and is now the subject of important changes proposed for the Ground Water Rule in the National Primary Drinking Water Regulations ${ }^{4}$.

- Sea water desalination, long thought to be too costly in the US, is now being implemented in Tampa, Florida as part of a master plan designed to provide new water to a region (10\% of the overall water supply by 2008$)$ whose groundwater resources can no longer supply the growing urban demand.

- The Ogallala formation in the central plains - an extensive fossil water aquifer with no effective recharge - is being depleted ever so slowly by agricultural and urban extraction, setting the stage for increasingly serious water supply problems in the future $^{5}$.

- The impact of climate change, as caused by global warming or longer-term natural cycles, is may affect water supply scenarios over the next fifty years, especially in California, where decreasing mountain snow pack storage may occur ${ }^{6}$.

- A recent dispute regarding reduced allocations of Colorado River water to California highlight the increasing difficulty and creativity required by competing urban, agricultural, and environmental interests to agree on a comprehensive conservation and plan to lower overall withdrawals over a mandated 15 year period $^{7,8}$. 


\section{CALIFORNIA AS A MORE FOCUSED EXAMPLE}

In many respects, California serves as an excellent example of many important water supply and quality problems facing the US and many parts of the world. Consider, initially, some pertinent facts ${ }^{2}$ :

- Direct precipitation provides most of the renewable water input to California each year, approximately 200 million acre feet (MAF) on average, of which approximately $65 \%$ is lost to evaporation and vegetative transpiration $\left(1\right.$ acre-foot $\left.=1233.5 \mathrm{~m}^{3}\right)$. The remaining 35\% comprises the State's average annual renewable runoff of about 71 MAF. Most of the runoff is stored in mountain snows, captured in numerous reservoirs, recharged to groundwater aquifers, or discharged to the Pacific Ocean.

- Over $30 \%$ of the average annual renewable runoff is unused and otherwise lost, primarily to the Pacific Ocean. Although it not explicitly designated for urban, agricultural, or environmental uses, its existence is deceiving, as it may be concentrated in wet years of the averaging cycle, and nonexistent in dry years. Small imports from the Colorado and Klamath Rivers (totaling about $6 \mathrm{MAF}$ ) are added with the remaining runoff total to compute the State's annual water budget. Of this, approximately

$\sim 28 \%$ is captured or otherwise used for irrigated agriculture,

$\sim 7 \%$ is captured or otherwise used for urban demands,

$\sim 35 \%$ is consumed by environmental allocations (such as mandated flows in wild and scenic rivers, the California Delta, and wetlands), and

$\sim 1 \%$ is for other uses such as power generation.

- Urban demands - primarily in the coastal areas - are growing and are basically being offset by surface water transfers from agriculture. Eventually, limitations, delivery restrictions and other political considerations may limit such transfers such that sources of "new" water must be found.

Because precipitation is concentrated in the North and in the winter, an interconnected surface water reservoir and aqueduct system has been built to store snowmelt water in reservoirs and redistribute water to users to in the growing population centers along the coast and the expanding agricultural users in the Central Valley. The California Delta forms the heart of this system. Water flowing through the Delta is subject to many forms of degradation, increasingly stringent environmental outflow and quality constraints, potential interruption from earthquake and levee failures, and a finite throughput capacity. The system is augmented by local groundwater use, which is significant ( $16 \mathrm{MAF} / \mathrm{year})$ and satisfies between 40 and $50 \%$ of the statewide agricultural and urban demands. In California, groundwater storage capacity is quite large, over $800 \mathrm{MAF}$, as compared with the surface reservoir capacity of $43 \mathrm{MAF}$, but may be limited by quality, sustainability, and other production-related constraints.

Although it has been said that there is "enough water in California" to meet future population (urban) demands for some time, capacity, water quality, and environmental constraints in the system are seen by many to prevent the kinds of redistribution and capture necessary to satisfy all demands in an economically feasible manner. 


\section{Where are things headed in California?}

Significant trends in population growth are likely to aggravate water shortages - today's average may be tomorrow's drought - sharply increase the cost of marginal increases in supply, and reduce the overall reliability of the system. Although water transfers from agriculture to urban use are here to stay, especially with increasing urbanization of former agricultural lands, there will be growing pressure to reallocate more water from agriculture to the environment, each of which will be subject to the capacity of the surface water system to move the right water around to the right places. Increasing the capacity of the system (more dams and aqueducts) is strongly limited by land and economic concerns.

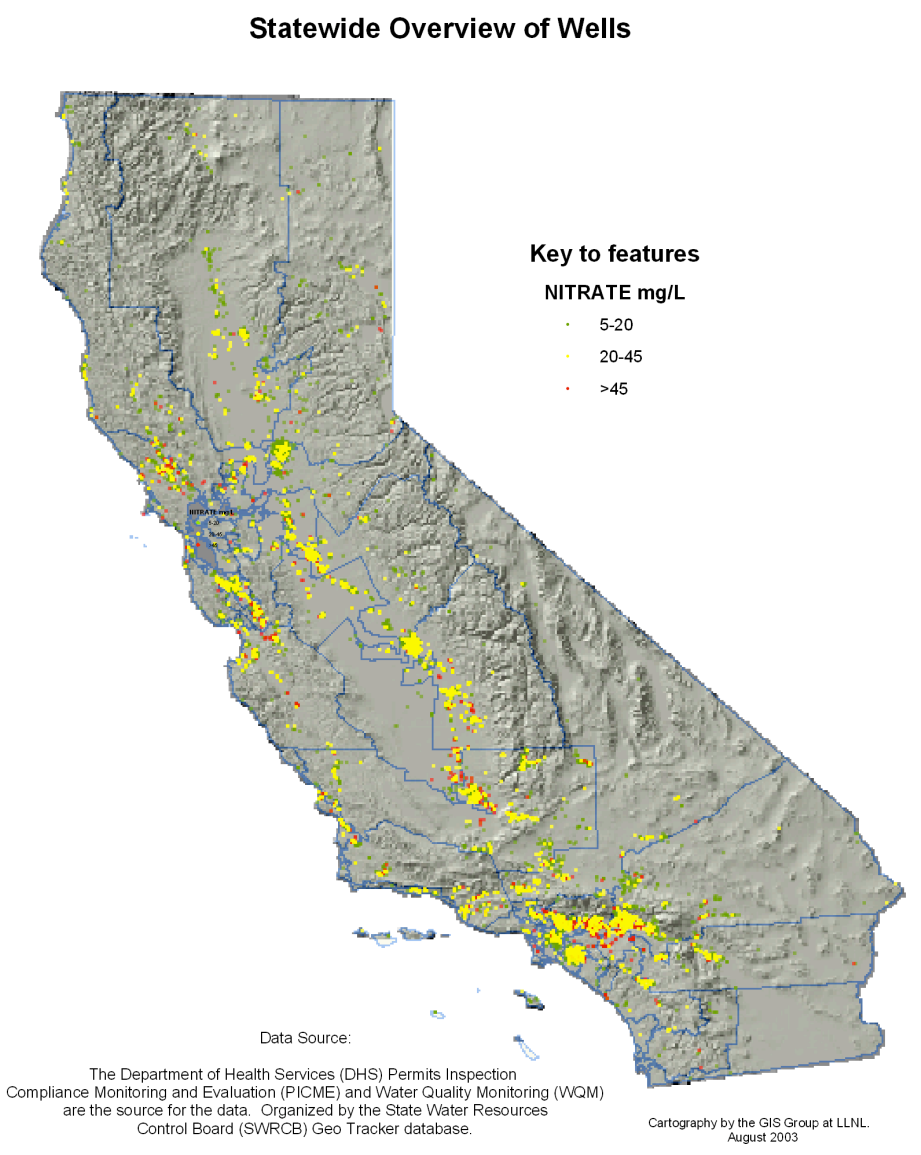

Figure 1: The extent of nitrate contamination in California groundwater. Low nitrate concentrations in green $(5-20 \mathrm{mg} / \mathrm{L})$, moderate concentrations in yellow $(20-45 \mathrm{mg} / \mathrm{L})$ and high concentrations in red that equal or exceed the regulated drinking water limit of $45 \mathrm{mg} / \mathrm{L}$.

Moreover, water quality problems in many parts of the state are beginning to limit the use of existing supplies and effectively reduce the amount of fresh water available. Groundwater quality in many areas, for example, is being threatened by fertilizer and pesticide contamination, farm wastes, septic discharges. One third of the public drinkingwater wells in the state have been lost since 1988 and nitrate contamination is the most common reason for abandonment. Currently, about 10 percent of active California public water-supply wells have nitrate contamination exceeding the drinking water standard of 
45 parts per million (Figure 1). In agricultural areas, such as Stanislaus County, up to 80 percent of groundwater is affected or polluted by nitrate. Accumulations of unhealthful natural minerals, such as arsenic and selenium, are found in irrigation discharges, and can become concentrated in wetlands or circulated into the California Delta. Arsenic itself is the focus of increasingly stringent regulated concentration limits. Degrading water quality in the Delta arising from agricultural wastes, lower flow rates, and saltwater intrusion is of considerable concern, both in terms of threats to drinking water quality, as well as fisheries and the natural ecosystem; these, in turn, will affect its overall role the California water system.

Persistent shortages in the urban areas will become the norm unless broader and more aggressive strategies for developing reliable sources of "new" water are pursued. In truth, there are only two real sources of water in California: (1) that derived ultimately from the hydrologic cycle and (2) seawater. Sources of new fresh water must either be derived from reallocations or more efficient use of the hydrologic input, reuse of impaired water (wastewater, agriculture drainage, polluted or non-potable groundwater), or from seawater itself. Notably, marginal increases in the supply can have a dramatic effect on costs (Figure 2).

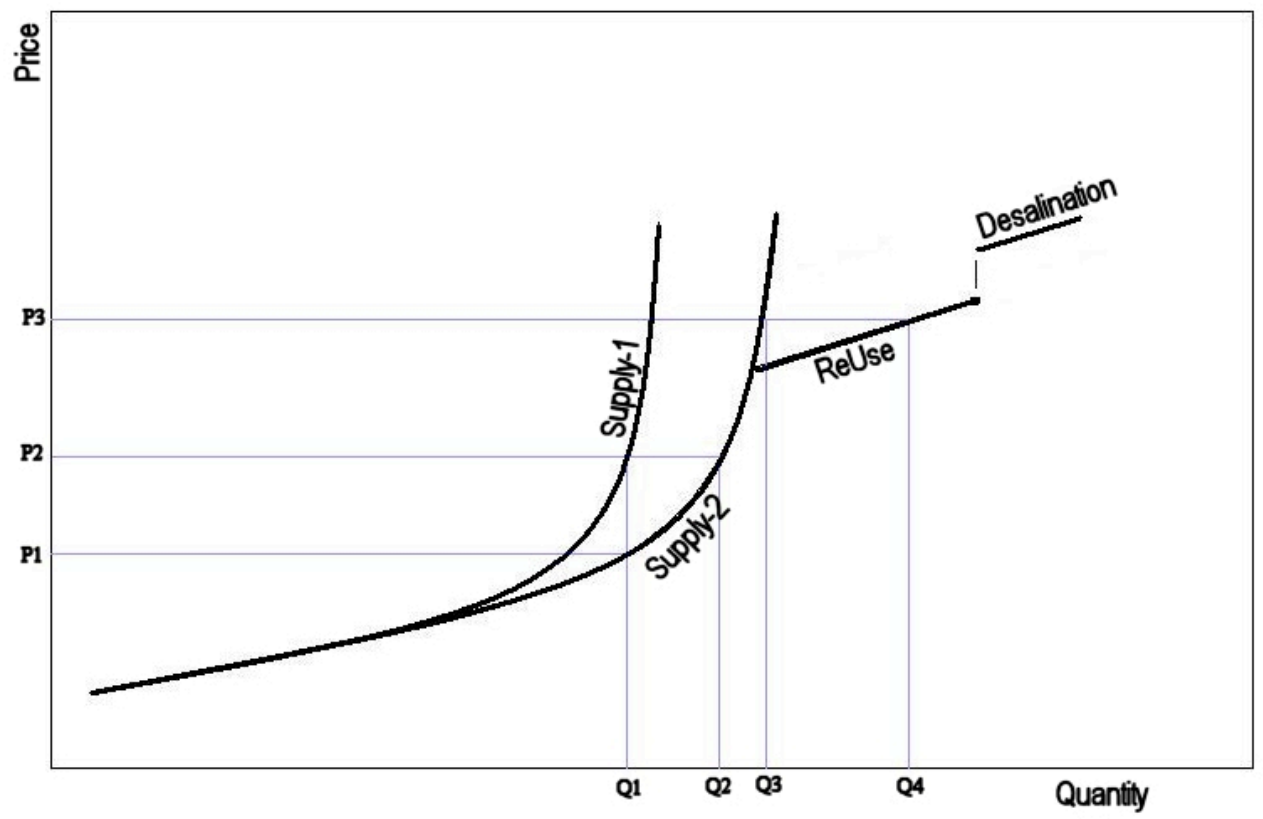

Figure 2: Increasing marginal costs of new fresh water supplies grow exponentially. Costs of reused or desalinated water tend to be less dramatic (courtesy, Dr. Norm Brown, Integrated Water Resources, Inc.)

In the near term, water reuse, as derived from wastewater treatment and agricultural drainage sources, will be particularly popular, yet subject to increased concerns with respect to water quality that are related mainly to salt and human pathogen loads (see example in next section). Water banking in underground aquifers, using fresh or reused water, is being used successfully in many areas, and is being considered for many others - especially if reclaimed water is used, if existing underground water is of poor quality in 
the first place, or if unhealthful natural minerals like arsenic and selenium are leached into the water in the process.

Over the longer term, the consensus of many is that desalination of ocean water or aggressive treatment of marginal, brackish, or otherwise unusable water - typically quite expensive - will become a routine source of new water, especially if more robust and economically viable treatment methods are found. In addition, the ability to predict changes and variability in climate over the next 50 years is becoming increasingly important to many water planners, especially as it relates to forecasting changes in the overall inputs to the California water system, changes in urban demand due to higher temperatures, or less snow in favor of more rain because of global warming ${ }^{6,9}$. Increased and more concentrated runoff from this latter scenario will undoubtedly lead to floods, the need for higher capacity in runoff and storage systems, or just smaller amounts of water that can ultimately be saved in existing reservoirs. Higher sea levels produced by melting ice caps will increase the penetration of saline water into the California Delta. These, in turn, may accelerate the need for developing reliable sources of new water iand improved water management strategies in California as described above and below.

What kinds of key, wide ranging science and technology (S\&T) developments can make a difference in California? Here, we wish to highlight three or four closely connected areas for S\&T development that could have a noticeable, practical, and meaningful impact on water in California (and by extension, elsewhere). In many senses, these are aligned with other recent national studies ${ }^{10,11}$ focused on elaborating the role of science in providing future water security in the $21^{\text {st }}$ century.

New Water: Improved water treatment technologies.

Here, we are concerned with the development of more cost effective methods for water treatment and purification, as it relates to seawater desalination, removal of salts and fertilizers from non-potable brackish groundwater or agricultural drainage, filtration of viruses or other pathogens from treated wastewater, or removal of other kinds of industrial or organic waste stream contaminants. One important S\&T issue here involves a need for more energy efficient reverse osmosis (RO) or electrodialysis based filtration designs, for example, new deionization techniques, point-of-use techniques, cheaper sources of energy, or some suitable combination of these or similar processes ${ }^{12}$. High energy costs of current RO technologies, for example, account for half of the total treatment cost, and far exceed the minimum theoretical thermodynamic energy for purification (Figure 3). If effective and viable at large enough scales or in a widelydistributed sense, more efficient technologies processes could serve to add "new" potable water into the California equation where it otherwise did not exist - through the effective reuse of wastewater or development of new water from seawater - thereby adding more reliability to the immediate users of this water and greater flexibility to other parts of the California water system. Another important S\&T issue involves the treatment of brines and other highly concentrated wastewaters produced by RO and related treatment methods. Although discharge to the ocean is often touted as the only real possibility, anther lies in the potential to extract commercially valuable minerals from the wastes themselves ${ }^{13}$. 


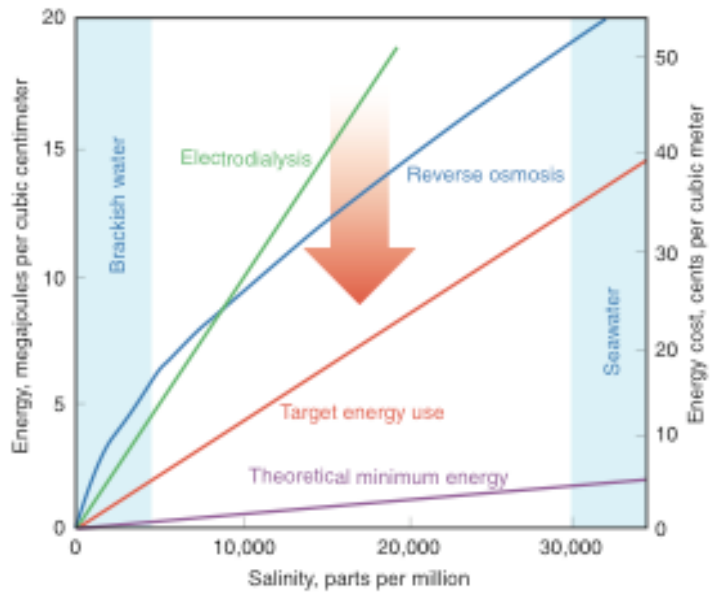

Figure 3. Energy required for desalination, as a function of concentration, for current RO and electrodialysis technologies, and the room for improvement for potential improved technologies $^{12}$.

Future Water: More reliable assessments of future climate change and variability. Here we are concerned with achieving a greater understanding of the future climate in California through prediction and observation, as it relates specifically to long term changes in precipitation and temperature, or shorter term fluctuations, typically manifested as droughts. Long term trends or changes in climate may result in more or less precipitation coming into the state, longer or shorter wet seasons, warmer temperatures that minimize accumulation of snow, and potentially rising sea levels. Precipitation changes will alter the water balance in the state and change the timing and way in which water is used, reused, moved, stored or procured - as, for example, through desalination. Even if precipitation amounts remain the same, less snow means that runoff will be concentrated in earlier months and potentially unavailable for reservoir storage (due to capacity and operational procedures) unless, for example, new forms of storage or alternative sources of water are found. Rising sea levels will induce salt water to flow further into the California Delta, affecting balances in the local ecosystem, as well as threatening water quality in the State's aqueduct system. The S\&T issue here really is one of developing (i) climate predictions at a fine-enough spatial resolution for use in California and over specific types of relevant time scales, (ii) the ability to reduce or quantify uncertainties that are involved in such predictions, and (iii) the ability to translate or propagate the results of such predictions into hydrologic variables such as runoff and groundwater recharge rates, that are pertinent to the needs of planners in local and statewide agencies.

\section{Banking Water: Impacts on groundwater quality.}

Here we are concerned with the use of groundwater basins for the storage of excess or reclaimed water, as recharged artificially through injection wells, infiltration basins, or ephemeral streams, or in the development of groundwater from degraded or low quality aquifers. Active water banking is already being used in many parts of the state (e.g., 
Kern, Los Angeles, and Orange Counties) and is being considered in some others (e.g., near Cadiz in the Mojave Desert). Many currently viable aquifers are being threatened with widespread salt loads from agriculture, while many others are naturally of poor quality - yet might be used if effective treatment techniques could be employed. The $\mathrm{S} \& \mathrm{~T}$ issue here is really one of understanding mechanisms that degrade or threaten groundwater quality, especially as they relate to the more aggressive uses of groundwater basins that are being considered or are in use. Issues to be addressed may include understanding the fate and migration of viruses in groundwater systems, developing gross balances of introduced or dissolved salts from agriculture or recharge practices, understanding the impacts of surface water - groundwater interactions on water quality, and so forth. A more in-depth example is presented below.

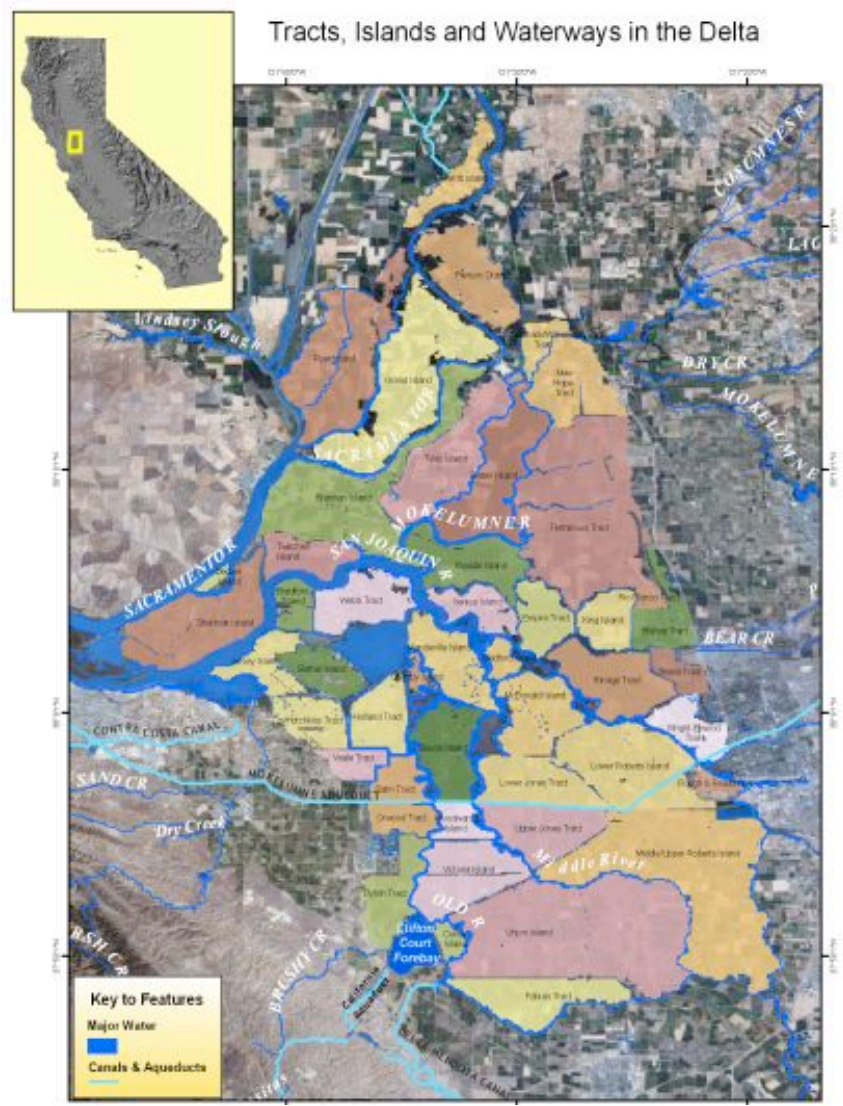

Figure 4. The California Delta

Delta Water: Understanding complex ecological trends and balances.

The California Delta is the heart of the State water system (Figure 4). Natural inflows from the North, West, and East normally discharge to the San Francisco Bay and the Pacific Ocean to the West. The Delta is an area of "unsurpassed ecological importance for salmon, migratory waterfowl, and a host of other plants and animals"14, yet it is also used to transfer water released from upstream reservoirs into aqueducts that flow to the South. Delta water quality and its interactions with the natural ecological system is affected by the quantity and quality of water moving into the Delta from inland sources 
or the San Francisco Bay, groundwater interactions between the channels and Delta islands, and other more complicated land use issues, both in the Delta and along the rivers that feed it. The S\&T issues here would really focus on trying to understand complex chemical and ecological cycles, especially as they are influenced by a combination of anthropogenic and natural forces, and their relation to the increasingly complicated and limiting environmental constraints being imposed to protect the Delta ecological system. The charter for addressing many of these issues lies with the recently established CalFed Program ${ }^{14}$, a cooperative effort of more than 20 state and federal agencies working with local communities to improve the quality and reliability of California's water supplies while preserving the San Francisco Bay-Delta ecosystem.

\section{AQUIFER BANKING IN ORANGE COUNTY, CALIFORNIA}

As a more illustrative example, we now review some recent and ongoing work to provide more scientific insight into the groundwater banking processes in a large urban setting.

The Orange County Water District (OCWD) manages a groundwater basin that provides $70 \%$ of the domestic water supply for approximately 2 million residents in the northern part of Orange County, California ${ }^{15}$. The remaining 30\% is purchased and imported from outside the district. On an average annual basis, roughly 270,000 acre-feet (AF) of water are extracted from several hundred production wells located within the middle production aquifers of the basin. To sustain this rate of withdrawal, OCWD maintains an artificial recharge program that returns about 205,000 AF of water, on an annual basis, to the groundwater basin. This is achieved by diverting large portions of the base flow of the Santa Ana River into a series of infiltration basins and abandoned gravel pits along or nearby the upper reaches of the river. Because of the higher geologic permeabilities in these areas, infiltrated water readily percolates into the main production aquifers.

Although the principal source of recharge comes from the Santa Ana River, additional supplies are occasionally imported from the Colorado River and California State Water Project sources. Future plans also call for direct use of reclaimed water from a nearby wastewater treatment plant to increase the overall recharge. Interestingly, much of the base flow in the Santa Ana River today is already reclaimed in the sense that it is partially composed of discharges from upstream wastewater treatment plants in Riverside County.

Reclaimed wastewater may contain organic and microbiological contaminants like viruses that, upon recharge into an aquifer, may later be captured in production wells, especially in the absence of tertiary or other advanced forms of wastewater treatment. Because dilution, natural degradation and other transformation processes may lower these contaminant concentrations along travel pathways, state regulators in California have proposed a nominal set of standards to govern how production wells and recharge practices involving reclaimed water are operated. In terms of the Orange County basins, they would require that (1) Reclaimed water have a groundwater residence time of one year before reaching production wells, as a way to ensure that degradation or dilution mechanisms occur; (2) No more than $50 \%$ of production well water may be reclaimed in 
its origin, regardless of residence time; and (3) Production wells be located more than $2,000 \mathrm{ft}$. from recharge basins.

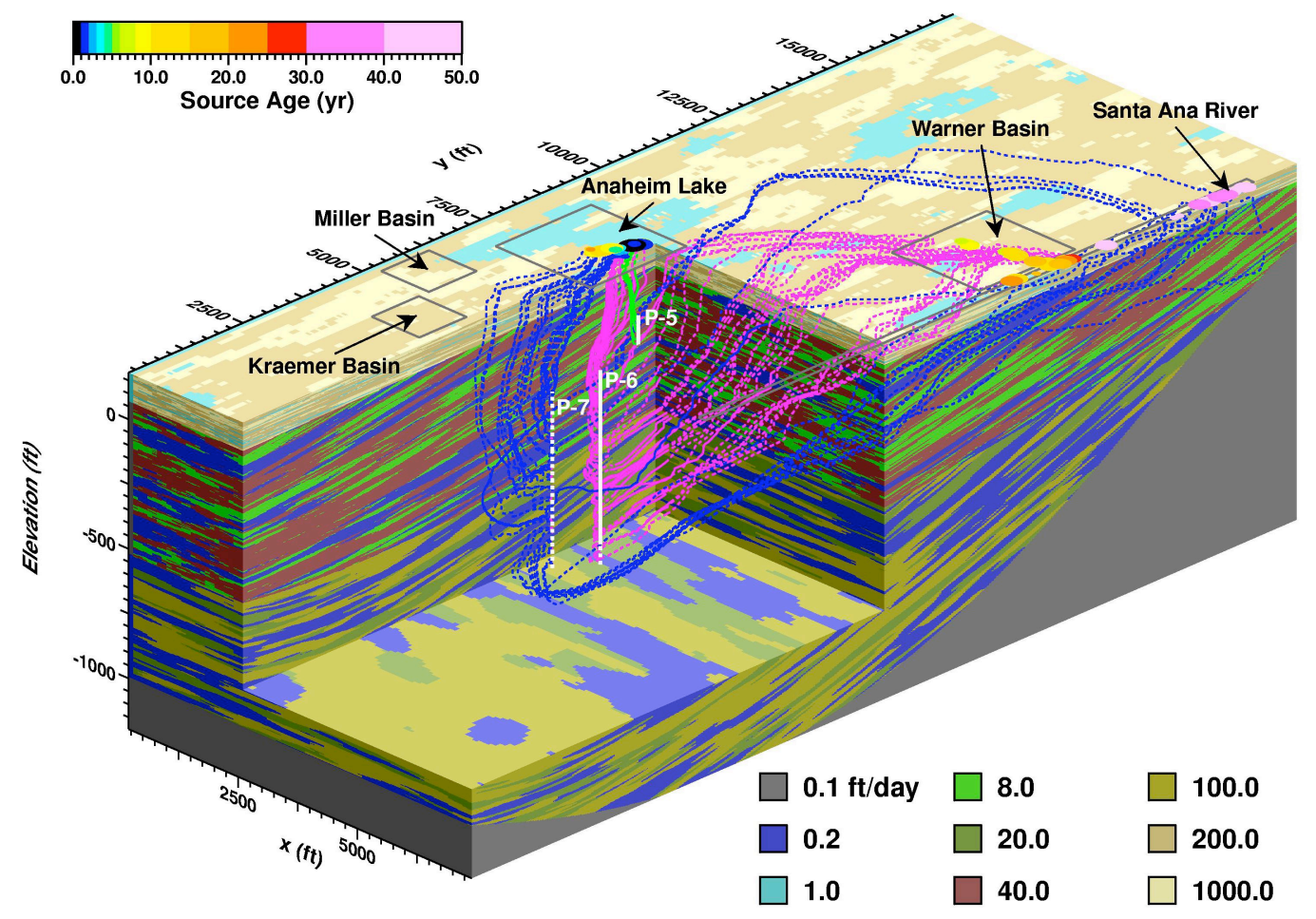

Figure 5: Perspective showing of simulated travel pathways from wells P5, P6, and P7 to their surface sources. Streamlines are color-coded to indicate the relevant capture well, and white areas along each well bore indicate their open intervals. The background block is coded to indicate complexity in the geology, hydraulic conductivity distribution. Dots represent intersection of streamlines with recharge surface and are color coded to travel time (after ref. 19).

Because these regulations are tentative, additional scientific study may be needed for their refinement. There have been no conclusive monitoring or epidemiological studies relating to the introduction and fate of viruses into the OCWD aquifer system, although viruses derived from similar artificial recharge operations have been observed in a nearby aquifer in Los Angeles County ${ }^{16}$. As a means to assess compliance with the proposed regulations, however, isotopic and modeling analyses have been used in the Orange County system to infer migration patterns of groundwater and estimate the ages and sources of groundwater in production and monitoring wells near the spreading basins ${ }^{17-20}$. 

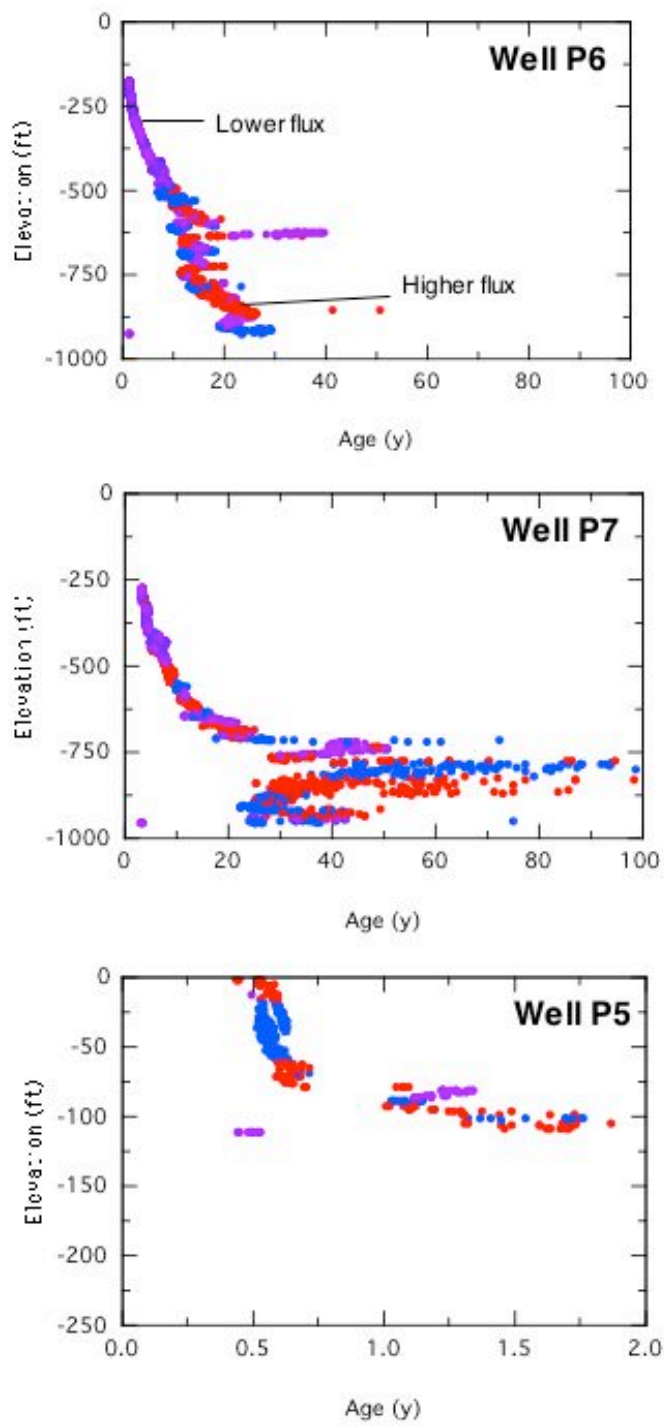

Figure 6: Model-predicted groundwater age as a function of depth below the water table for wells P6, P7, and P5. Colors represent relative rate of flow into each well at particular depths, as controlled by neighboring geologic conditions (after ref. 20).

Figure 5 shows a figure from a modeling study ${ }^{20}$ that shows approximate flow pathways from three production wells, labeled as 'P5', 'P6', and 'P7', back to their surface water sources. These sources are represented, primarily, by three recharge basins (Anaheim Lake, Warner basin, and the Santa Ana River). Other production wells exist but, for clarity, are not shown. Note that wells P6 and P7 are deep and have large open production intervals, while P5 is shallow and only has a small open interval. For each well, the travel pathways envelop a distorted "capture zone" around a body of water that flows uniquely into each well through a complicated geological setting. The point is that the "age" of the water entering each well is not unique, but, rather, distributed as a function of the recharge pathways for each well. Small and shallow wells such as P5 
would tend to have younger ages, while deeper wells like P6 and P7 will have older ages. This is obvious in Figures 6 and 7, which show the groundwater age as a function of depth and as a histogram in each of these wells.

The mean ages in each well, as determined from the results in Figure 7, were similar to tritium/helium age dating estimates determined for "average water" extracted from the entire open interval of each well. Although the age estimates were useful in calibrating the simulation model, they were not wholly indicative of the age distribution in any of the wells, and thus were not as completely useful for demonstrating compliance with the aforementioned proposed regulations as originally envisioned. Notably, from the simulation results, no water entering wells P6 and P7 is younger than 1 year in age, although more than half of the water entering well P5 is.
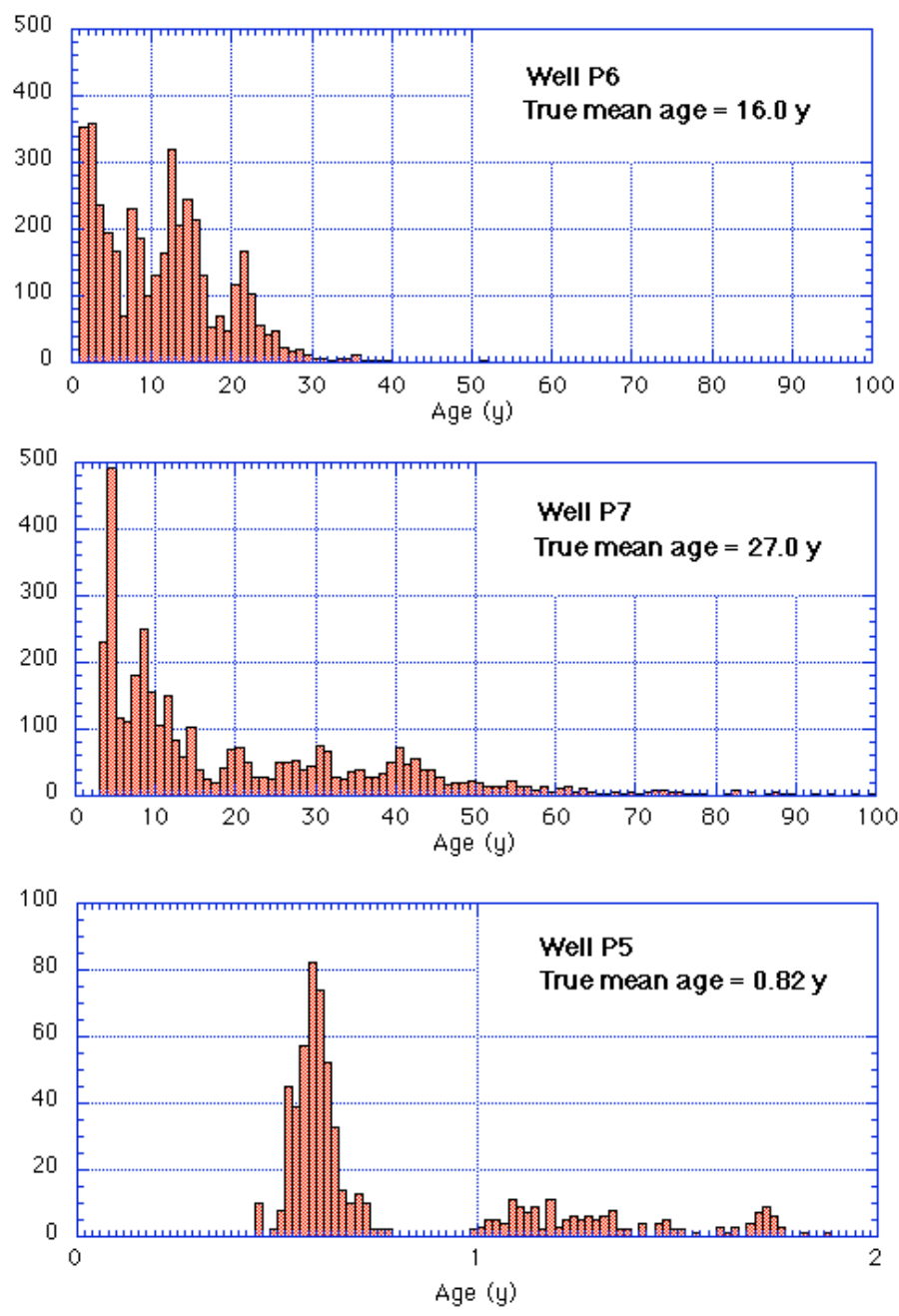

Figure 7: Flux-weighted distribution of model-predicted groundwater ages for wells P6, P7, and P5. One-year intervals shown for P6 and P7 histograms; one week intervals shown for P5 histogram (after ref. 20). 
As a result of these observations, a tracer test was conducted during a recharge event in nearby Anaheim Lake to see whether any "first arrivals" would appear in any of the various production wells surrounding the lake within a 1-year time period ${ }^{17}$. A small amount of a Xenon isotope $\left({ }^{124} \mathrm{Xe}\right)$ was introduced in the lake as the tracer. Figure 8 shows measurements of ${ }^{124} \mathrm{Xe} /{ }^{132} \mathrm{Xe}$ ratios observed in three deep wells (P6, P7, and P8) surrounding the lake over a 400 day period following the recharge event. Although there was no appreciable arrival of the tracer in wells P6 and P7 during this time (apparently consistent with the results in Figures 5-7), there was an obvious arrival in well P8.

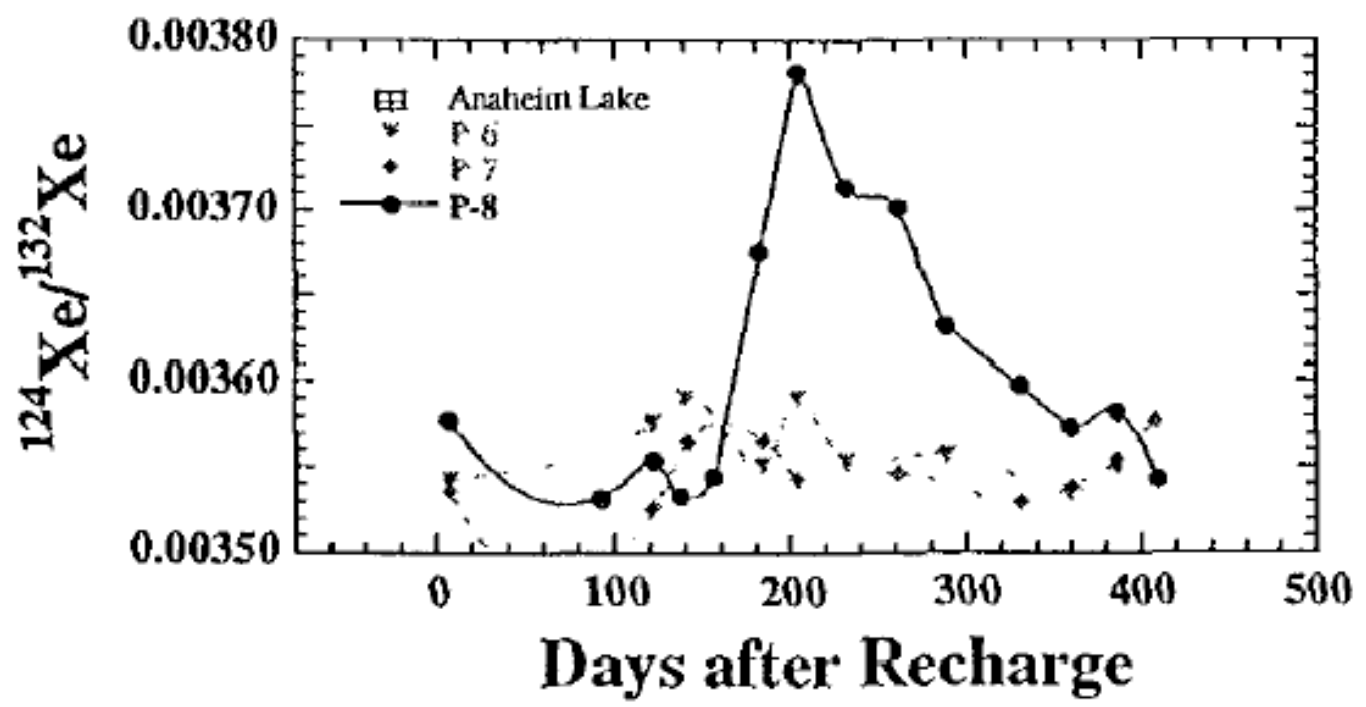

Figure 8: ${ }^{124} \mathrm{Xe} /{ }^{132} \mathrm{Xe}$ ratios observed in deep wells $\mathrm{P} 6, \mathrm{P} 7$, and P8 following tracer injection during a recgharge event in Anaheim Lake (after ref. 17). Observations suggest $\mathrm{a}<1$ year travel time component to the well P8, but nothing so short to wells P6 and P7.

Now, although age and travel time data for P8 were not included in the information in Figures 4 and 5, it should be noted that all three wells are similar in their deep penetration into the aquifer, their large open intervals, their close proximity to one another, and a mean groundwater age that is over ten years for each well. Neverthelesss, the tracer test indicated a relatively fast travel pathway between Anaheim Lake and P8 that is not apparent in the other two wells. Our interpretation of this observation is that it reflects the complicated nature of the geologic system that controls groundwater flow in relatively small areas, and that "statistically" different results of this sort are reasonable to expect in such natural systems. In a broader sense, the results indicate that the current wells, or even nearby "untested" wells of similar design have a plausible chance for having 1-year old water components, and that the relationship of these findings to the proposed regulations and the more fundamental concerns about pathogen transport may deserve additional consideration.

\section{CONCLUSIONS}

The problems and difficulty in providing clean and reliable water to the world's population in the $21^{\text {st }}$ century remain among the most challenging tasks for the human 
race. In addition to the important role that the world's political, social, and economic institutions play in addressing these issues, there will always be a correspondingly strong and focused role for the world's science and technology establishments in this effort. The need for improved communication and integration across the spectrum of institutions that deal with water canot be understated.

In this paper we have discussed several scientific challenges that face the State of California with respect to securing reliable water supplies in the future. These concern, primarily, understaning impacts of future climate change and climate variability, the long term effects on water quality and ecological health produced by industry, agriculture, and various land use practices, primarily over the past century, and the technical challenges we face in developing "new" water through advances in treatment, purification, and reuse practices.

As an example we reviewed, albeit briefly, a detailed modeling an isotopic study related to a water banking operation in an urban setting in Southern California. The ultimate water quality concerns here are related to the potential introduction of viruses and other pathogens from treated wastewater into the aquifer and the ultimate viability of several proposed "surrogate" regulations designed to protect the quality of water produced from the aquifer. The model - albeit complicated - and the tracer tests proved to be powerful tools to examine the behavior of the system and provide insights related to compliance with the proposed regulations. We believe, in addition, that these techniques may continue to offer a strong scientific basis to explore more directly the fate of viruses and pathogens introduced into such systems, the concern that motivated the regulatory interest in the first place $^{21}$.

\section{ACKNOWLEDGEMENTS}

This work was performed under the auspices of the U. S. Department of Energy by the University of California, Lawrence Livermore National Laboratory under Contract No. W-7405-Eng-48.

\section{REFERENCES}

1. Gleick, P., ed., 1997. Water in Crisis: A Guide to the World's Fresh Water Resources, Oxford University Press.

2. California DWR, 1998. The California Water Plan Update, Bulletin 160-98, California Department of Water Resources, Sacramento, CA.

3. National Research Council, 1984. Groundwater Contamination, National Academy Press, Washington DC.

4. USEPA, 40 CFR Parts 141 and 142, National Primary Drinking Water Regulations: Ground Water Rule; Proposed Rule, United States Environmental Protection Agency, Federal Register, 65(91), May 10, 2000 / Proposed Rules, 30194-30274.

5. Bittinger, M. W., and E. B. Green, 1980. You Never Miss the Water till ... (The Ogallala Story), Littleton: Water Resources Publications, Littleton, CO. 
6. Dettinger, M.D., D.R. Cayan, 1995. Large-scale atmospheric forcing of recent trends toward early snowmelt runoff in California. Journal of Climate 8:606-623.

7. Quantification Settlement Agreement, 2003. http://www.saltonsea.water.ca.gov/crqsa/index.cfm

8. US Department of the Interior, 2003. Record of Decision, Colorado River Water Delivery Agreement, Implementation Agreement, Inadvertant overrun and Payback Policy, and Related Federal Actions, Final Environmental Impact Statement.

9. Snyder, M. A., J. L. Bell, L. C. Sloan, P. B. Duffy and B. Govindasamy, Climate responses to a doubling of atmospheric carbon dioxide for a climatically vulnerable region, Geophysical Research Letters, 29(11), 9-1 - 9-4, 2002.

10. National Research Council, 2001. Envisioning the Agenda for Water Resources Research in the Twenty-First Century, National Academy Press, Washington DC.

11. National Research Council. 2004. Confronting the Nation's Water Problems: The Role of Research, National Academy Press, Washington DC.

12. Heller, A., 2004. Helping Water Managers Ensure Clean and Reliable Supplies, in Science and Technology Review, July/August, 2004. Lawrence Livermore National Laboratory, Livermore CA (UCRL-TR-52000-04-7/8)

13. Bourcier, W. L., M. Lin, G. Nix, 2003. Recovery of Minerals and Metals from Geothermal Brines, Lawrence Livermore National Laboratory, Livermore CA (UCRL-JC-153033).

14. http://calfed.ca.gov/

15. OCWD. Groundwater Management Plan, 1991 Update. Orange County Water District, Fountain Valley, CA, 1991.

16. Yanko W. A., J. L. Jackson, F. P. Williams, A. S. Walker, and M. S. Castillo, 1999. An unexpected temporal pattern of coliphage isolation in ground waters sampled from wells at varied distance from reclaimed water recharge sites. Water Research 33, 53-64, 1999.

17. Davisson M. L., G. B. Hudson, R. Herndon, S. Niemeyer, and J. Beiriger, 1996. Report on the feasibility of using isotopes to source and age-date groundwater in Orange County Water District's Forebay Region, Orange County, California. UCRLID-123593, Lawrence Livermore National Laboratory, Livermore, CA.

18. Davisson M. L, G. B. Hudson, J. B. Moran, S. Niemeyer, and R. Herndon, 1998. Isotope tracer approaches for characterizing artificial recharge and demonstrating regulatory compliance. Proceedings, Annual UC Water Reuse Conference, Monterey, CA, June 4-5,1998, WateReuse Foundation, Alexandria, VA, 1998.

19. Williams, A. E., 1997. Stable isotope tracers: natural and anthropogenic recharge, Orange County, California. Journal of Hydrology, 201,230-248.

20. Tompson A. F. B, S. F. Carle, N. D. Rosenberg, and R. M. Maxwell, 1999. Analysis of groundwater migration from artificial recharge in a large urban aquifer: A simulation perspective. Water Resources Research, 35, 2981-2998.

21. Maxwell, R. M., C. W. Welty, and A. F. B. Tompson, 2003, Streamline-based simulation of virus transport resulting from long-term artificial recharge in a heterogeneous aquifer. Advances in Water Resources, 26(10), 1075-1096, 2003 


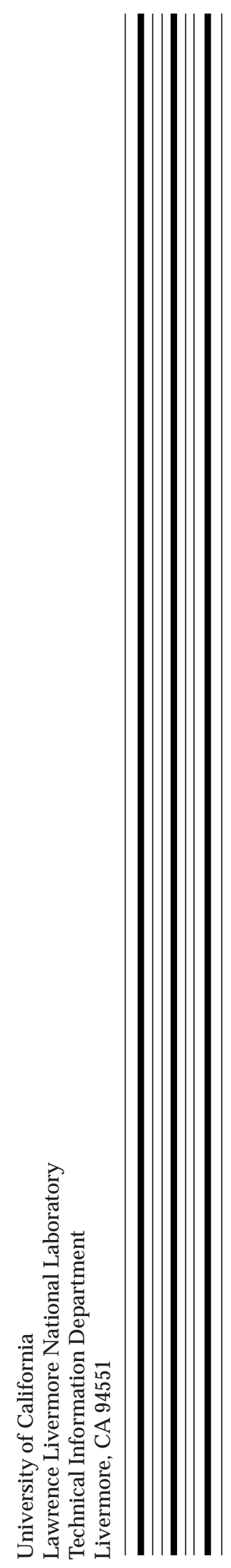

